\title{
EVALUATION OF THERMAL INSULATION OF THE GASTRONOMIC REFRIGERATION FURNITURE PROTOTYPE
}

\author{
Tomasz Bernat* \\ * Institute of Machines and Motor Vehicle (IMRiPS), Poznan University of Technology, 60-965 \\ Poznań, Poland, e-mail: tomasz.bernat@put.poznan.pl, ORCID 0000-0001-8613-594X \\ *Corresponding author: e-mail: tomasz.bernat@put.poznan.pl

\begin{tabular}{l}
\hline ARTICLE INFO \\
\hline Article history: \\
Received: March 2021 \\
Received in the revised form: April 2021 \\
Accepted: May 2021 \\
\hline Keywords: \\
refrigeration furniture, \\
thermal insulation material, \\
polyurethane foam
\end{tabular} \\ ABSTRACT \\ An innovative method of insulation by injection to a cooling tank was \\ investigated with consideration of a sustainable development need du- \\ ring production of thermo-insulation materials. An insulation material \\ consisted of polyurethane foam. The manufacturer has chosen HFO ga- \\ ses for filling in the pores, since this is a product with a low environ- \\ mental impact. HFO gases have a zero potential for destruction of the \\ ozone layer and an extremely low global warming potential. Cooling \\ tanks insulated with modern technologies of injection of polyurethane \\ foam were investigated with regard to heat permission. They were also \\ tested on account of occurrence of heat leakage bridges. The investiga- \\ tion covered also cooling furniture insulated with a conventional met- \\ hod of gluing ready-made polyurethane boards. The tests showed that \\ a modern insulation technology influences reduction of the heat permis- \\ sion coefficient towards the presently applied technology. The investi- \\ gated insulation of cooling furniture did not prove any heat leakage \\ bridges. Therefore, it may be concluded that the technological process \\ is correct. Cooling tanks manufactured in the present insulation techno- \\ logy did not show the occurrence of heat leakage bridges.
}

\section{Introduction}

Since the global energy problems are deepening, the focus should be on thermal insulations when considering heat exchange technologies. The insulation acts as resistance to thermal energy flow. Main functions of thermal insulation include energy maintenance, temperature control and heat exchange control. In many texts concerning heat exchange, electric analogy was applied to explain a physical meaning of heat transmission (Page, 1991; Wiśniewski and Wiśniewski, 2000; Incropera and DeWitt, 2002). In this context, the material resistance to thermal energy flow is defined as inversely proportional to the material thermal conductivity. A suitable insulation material has a high resistance to heat exchange and a low thermal conductivity coefficient. Calorific effect was defined as a level of insulation capacity and is inversely proportional to the thermal conductivity. Foam insulation was designed to achieve high efficiency. 
Polyurethane foam as an insulation material included at the beginning chlorofluorocarbon (CFC) as a foam-forming gas closed in cell structures of foams with a low thermal conductivity coefficient. Such insulation is the most effective thermal insulation system - next to air (Moreno, 1991; Kuhn et al., 1992) since heat conduction of air is about threefold higher than CFC gas and heat exchange takes place through conduction (Ostrorsky et al., 1986; Bernat et al., 2019).

The growing anxiety with a threat of depletion of the ozone layer and global warming led to withdrawing the CFC in 1996 (United Nations Treaty Collection. Chapter XXVII 2.a Montreal Protocol on Substances that Deplete the Ozone Layer, 1987). Alternative blowing agents, although less environmentally harmful ensured foam insulation with a higher heat conduction coefficient. No availability of gases that could ensure a low heat transfer of foam insulation constituted a basis for development of more efficient insulation materials with a lower negative impact on the environment and with properties that are higher than CFC gases parameters. As a result, methods of development of the advanced techniques of thermal insulation are becoming a foundation for further research.

The performed development work has led to development of alternative insulation materials in the form of natural products such as starch (Machado et al., 2017; Vargas-Torres et al., 2017), lyophilisates (Góral et al., 2018; Kozłowicz et al., 2019) Currently, instead of CFC gases, hydrocarbons are used (cyclopentane, isopentane), fluoro-olefins (HFO), carbon dioxide and oxygen as well as vapour (Brodt, 1995; Jarfelt and Ramnäs, 2006; Honeywell International Incorporation, 2021). Thermal conductivity of insulation foam depends on the conduction of gases mixture in cells, solid body conduction (polymer) and radiation between the cells (Jarfelt and Ramnäs, 2006). Reduction of the foam density and gas cells causes reduction of thermal radiation and heat conduction in the solid body. Conduction in the cell structure through the mixture of gases constitutes a decisive majority with regard to the total amount of heat exchange in foam. Circa $75 \%$ of the foam insulation ability results from the applied mixture of cell gases whereas the size and density of cells is responsible for the remaining part of the thermal insulation ability of the material (Jarfelt and Ramnäs, 2006; Sobolewski and Błażejczyk, 2014).

The objective of the research is the evaluation of the thermal insulation of tanks used in cooling furniture for storing of products in serving lines with a lowered temperature (e.g., vegetable and fruit salads) made on the specially developed innovative production stand found in KOMAT Mieczysław Kozłowski company in Romanów Dolny (Bieńczak et al., 2020). The quality of the insulation is proved by the average value of the heat transmission coefficient and no heat leakage bridges (Bieńczak et al., 2004; Perz, 2005).

\section{Research method}

\section{The test object}

The first stage of the research was preparation of the object, namely, a thermally insulated tank as shown in fig. 1. The cooling tank consisted in the walls made of stainless steel and a core made of thermo-insulation material. 


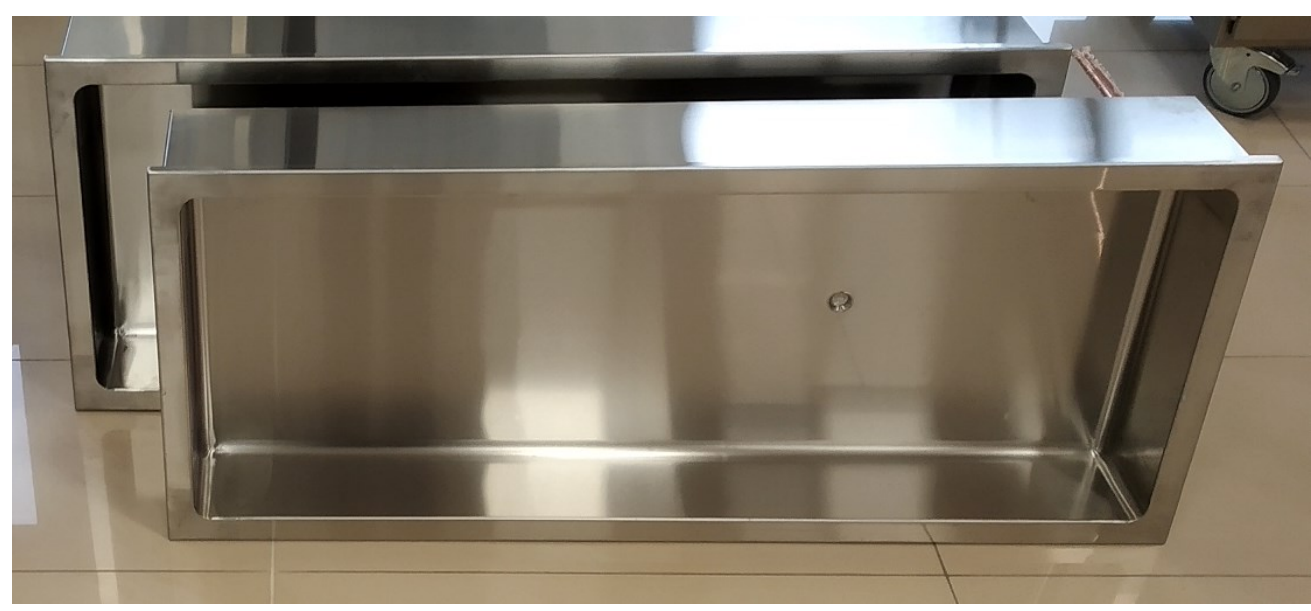

Figure 1. Thermally insulated cooling tank

As a part of the investigation, thermal permeability coefficients of the insulation were measured with the use of the measuring device AHLBORN ALMEMO 2590 and with the heat stream density sensors ALMEMO ZA9007FS and heat leakage bridges were analysed in the developed furniture with the use of thermovision pyrometer FLIR TG167. During the research, tanks insulated with a conventional method of insulation from glued boards and insulations made with an innovative method, namely, injection of polyurethane foam between tank walls were compared.

\section{The research procedure}

To ensure independence of measurements from the influence of external factors, a thermally insulated cooling tank was insulated from the environment with a styrofoam board as shown in figure 2. An electric heating device and fans were placed inside the object to ensure equal distribution of the heated air. Thermoelectric sensors placed outside and inside the object were used for measurement of the temperature. An optimal difference of temperatures between the inside of the tank and the environment was $30^{\circ} \mathrm{C}$. So prepared stand was maintained in the controlled temperature for 48 hours to ensure the stationary state (Wiśniewski and Wiśniewski, 2000; Incropera and DeWitt, 2002).

To determine the heat stream density of the cooling tank insulation, an auxiliary wall method proved to be useful. This method is used for the studies on thermal conductivity of materials or thermal resistance of multi-layer partitions both in laboratory samples and in the already made thermal partitions. Fig. 3 shows the realization of the method (Bieńczak et al., 2004). 


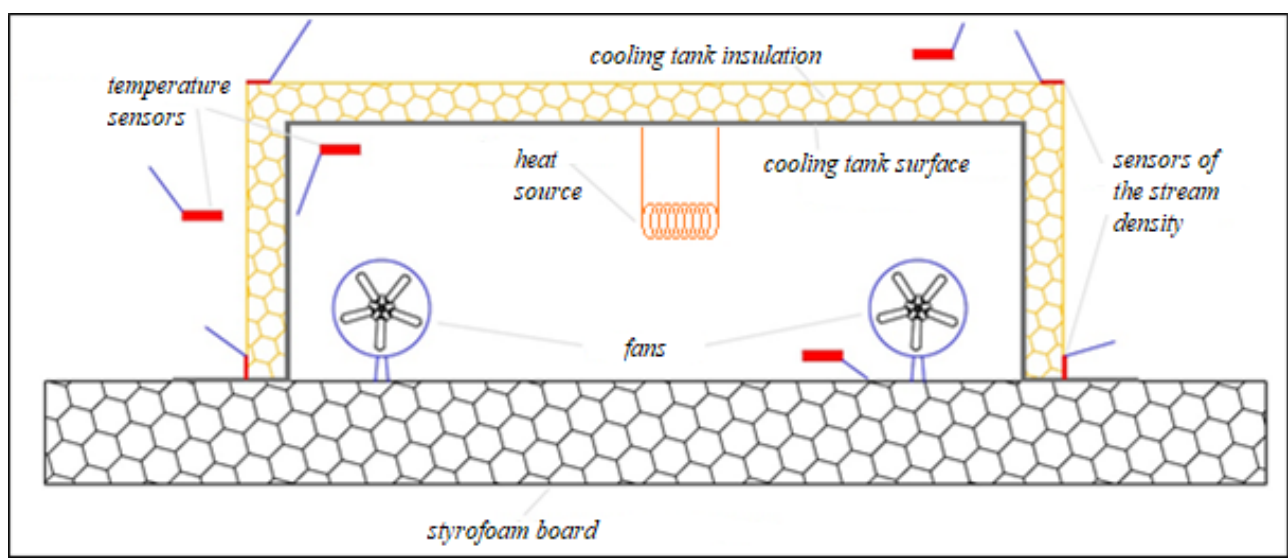

Figure 2. Schematic representation of the test stand

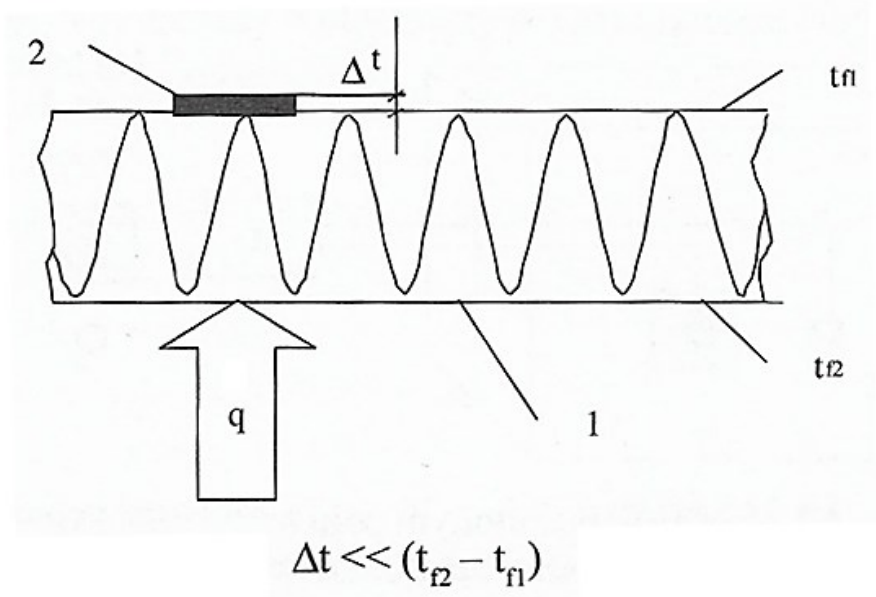

Figure 3. Determination of the heat flowing stream with the auxiliary wall method; 1 - thermoinsulation system, 2 -sensor "auxiliary wall "type, $t_{f 1}, t_{f 2}$-temperatures on the thermoinsulation system walls, $\Delta t$ - reduction of temperature on the auxiliary wall, $q$-density of the heat flowing stream

The measurement is based on the assumption that the heat stream density $q$ flowing through the investigated partition in the stationary state is equal to the heat stream density $q_{\mathrm{o}}$ flowing through the auxiliary wall whose thermal conductivity coefficient $\lambda_{\mathrm{o}}$ is known (Wiśniewski and Wiśniewski, 2000; Incropera and DeWitt, 2002). The stand after the start was left to obtain the stationary state so that in the investigated elements heat accumulation occurs. For the stationary state, thermal input of the heat source is equal to the thermal input permeating through the partition (Wiśniewski and Wiśniewski, 2000; Incropera and DeWitt, 2002). 
In order to realize the set plan, the following parameters were measured:

- the heat stream density $q\left(\mathrm{~W} \cdot \mathrm{m}^{-2}\right)$ permeating though the tank surface and the insulating material,

- temperature: $T_{w}\left({ }^{\circ} \mathrm{C}\right)$ inside the tank, $T_{z}\left({ }^{\circ} \mathrm{C}\right)$ outside the tank,

When the necessary data were obtained, heat permission coefficient was calculated:

$$
U=\frac{q}{\Delta T}\left(\mathrm{~W} \cdot \mathrm{m}^{-2} \mathrm{~K}\right)
$$

where:

$$
\begin{array}{ll}
q & \text { - heat stream density, }\left(\mathrm{W} \cdot \mathrm{m}^{-2}\right) \\
\Delta T & \text { - difference of temperatures, }(\mathrm{K})
\end{array}
$$

In the realized task, it was required to evaluate the obtained values of the heat permission coefficient $U$ for the selected cooling tanks. The measurements were determined for 18 cooling tanks including 9 insulated with glued boards of polyurethane foam (according to numbering A1-A9) and for 9 insulated by injection of the polyurethane foam (according to numbering B1-B9) on the prototype of the machine.

In all the investigated tanks, sensors for measurement of the heat stream density $q$ were distributed equally on the bottom surface of the tank. Moreover, in six the biggest tanks with regard to their capacity, two side surfaces - a narrow and wide one were subjected to investigations. Measurements were carried out in 10 iterations for each variant. Figure 4-6 present a manner of distribution of measuring sensors during the studies.

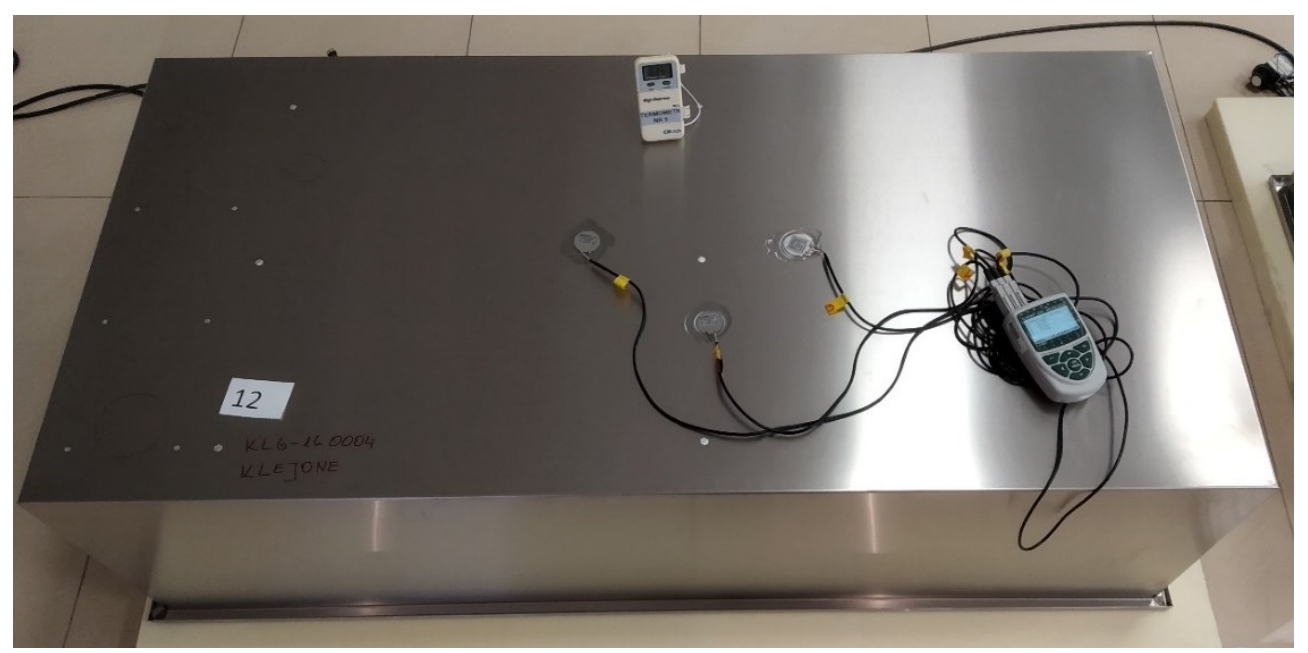

Figure 4. Manner of distribution of measuring sensors on the bottom wall of the cooling tank 


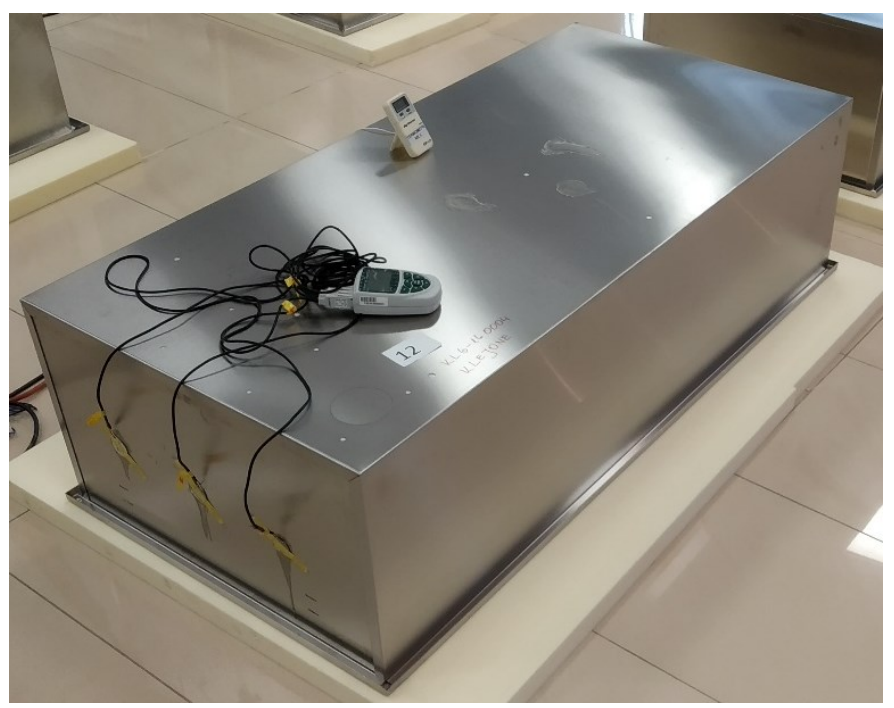

Figure 5. Manner of distribution of measuring sensors on the side (short) wall of the cooling tank

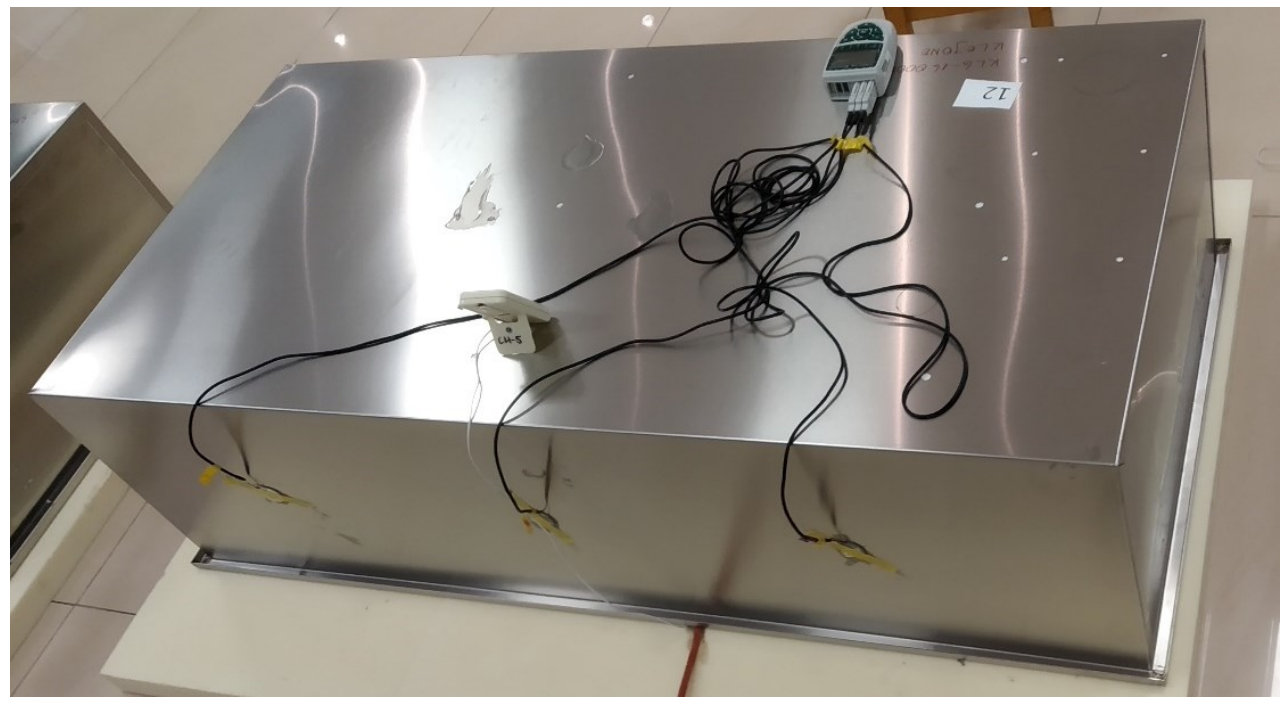

Figure 6. Manner of distribution of measuring sensors on the side (wide) wall of the cooling tank 


\section{Results and discussion}

\section{Assessment of heat transfer coefficients}

After the thermal analysis of temperature distribution was performed with regard to the typical geometry of the cooling tank, it was stated that the cooling tank due to its specific distribution of temperature fields is characterised with temperature stratification. It means that in the cooling tank, except for the internal natural convection, conductivity takes place. Natural convection may take place only on the tank edges. This specific type of the temperature distribution is known as stratification (Khalifa et al., 2011; Bernat et al., 2019). Simulation of the temperature distribution was presented in figure 7.

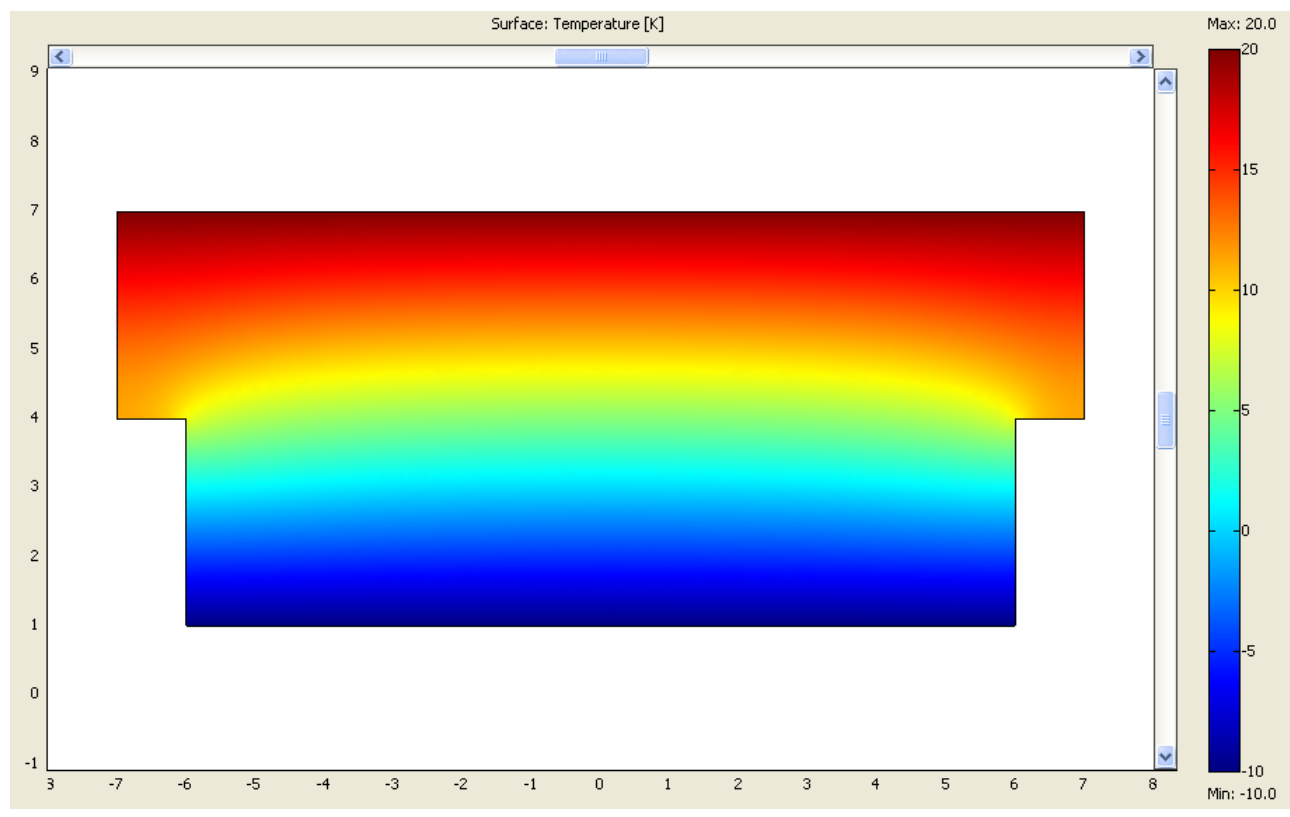

Figure 7. Stratification of the temperature distribution in the cooling tank (Bernat et al., 2019)

Fig. 8-9 presents the set of the obtained values of heat transfer coefficients $U$ with determination of pairs: a cooling tank with glued insulation - a cooling tank with a foaming insulation. In each of the investigated cases, a new type of the applied insulation (with a foaming method) proved to be better than the current method, i.e., the method of gluing ready-made polyurethane boards since the coefficient $U$ has a lower value. 


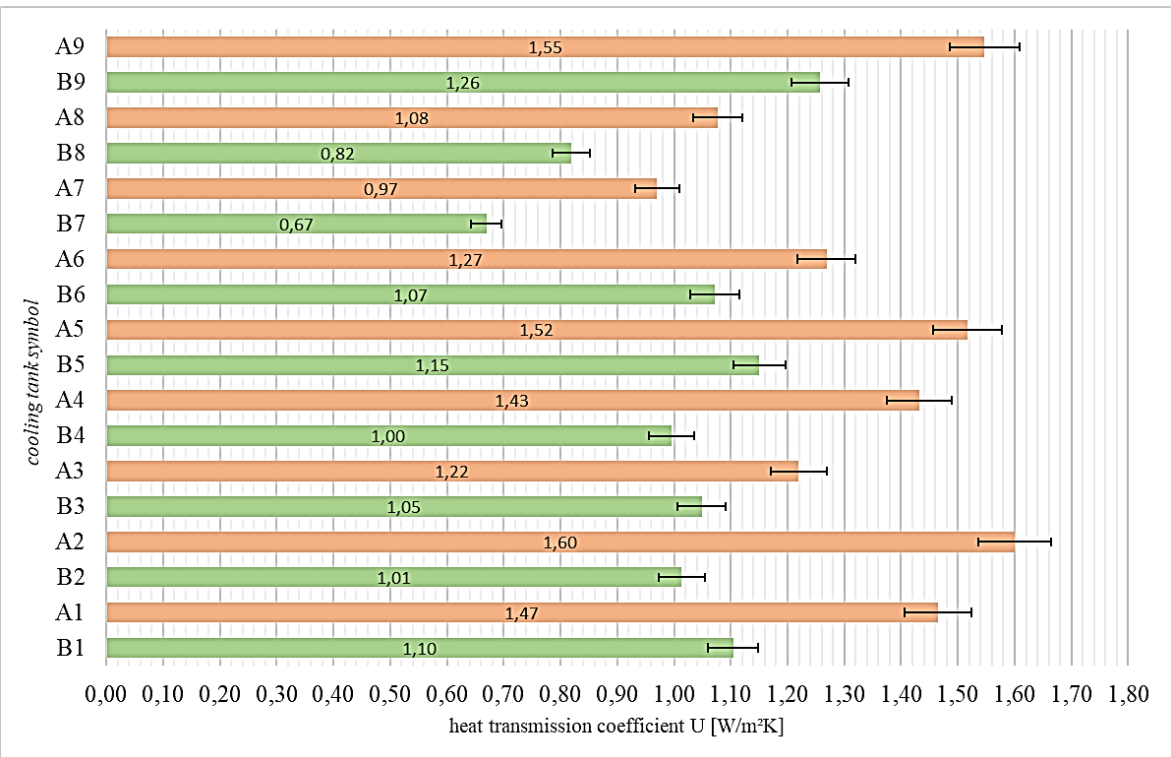

Figure 8. The set of the obtained values of heat transmission coefficients $U$ with determination of pairs: a cooling tank with glued insulation - a cooling tank with a foaming insulation.

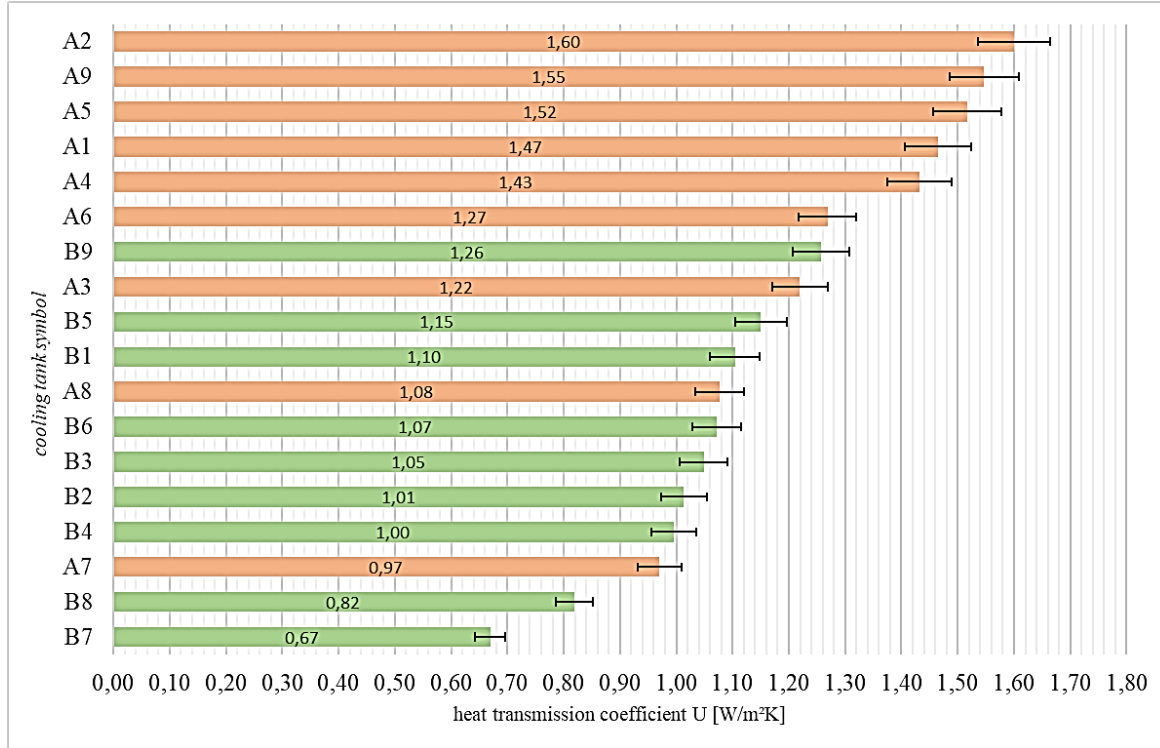

Figure 9. The set of the heat transmission coefficients $U$ in a growing manner 
Evaluation of thermal insulation...

The performed comparative studies of 9 types of tanks enable assessment of the impact of the change of the insulation technology on the heat flow through the walls. The efficiency of insulation was determined quantitatively with the heat transmission coefficient through the insulated wall $U$. Since, during the measurements, a probability of convection boundary conditions, namely heat transmission coefficients on both sides, the only variable was the type of the used insulation. As shown in figure 8-9 in all cases of 9 types of tanks, the insulation made with the foam filling technology between the tank and casing was thermally more effective than the insulation made of glued boards of the insulation material.

Analysis of the obtained results in comparison to the literature studies shows that the tank construction has a considerable impact on the obtained heat transfer coefficients. The tank casing, namely stainless steel, may cause the increase of the final value of the coefficient. The literature study clearly confirms this relation (Góral et al., 2013; Perz et al., 2018). Table 1 presents the set of the obtained and selected literature heat transmission coefficients $U$ and heat transfer coefficients $\lambda$ for the thermal partition made of the $0.04 \mathrm{~m}$ insulation.

Table 1.

The set of heat transfer $U$ and heat transmission $\lambda$ coefficient for the partition with thickness $0.04 \mathrm{~m}$.

\begin{tabular}{lcc}
\hline \multirow{2}{*}{ Insulation material } & \multicolumn{2}{c}{ Coefficient } \\
\cline { 2 - 3 } & of heat transmission $U\left(\mathrm{~W} \cdot \mathrm{m}^{-2} \mathrm{~K}\right)$ & of heat transfer $\lambda\left(\mathrm{W} \cdot \mathrm{m}^{-1} \mathrm{~K}\right)$ \\
\hline Glued polyurethane foam & 1.34 & 0.059 \\
Injected polyurethane foam & 1.01 & 0.045 \\
Styrofoam & $0.95-1.02$ & $0.041-0.043$ \\
Lyophilizated foams & 0.75 & 0.03 \\
Aerogels & $0.3-0.45$ & $0.012-0.018$ \\
\hline
\end{tabular}

In the research that has been performed so far (Perz et al., 2018) the authors present the heat transmission coefficient of the styrofoam as $0.95-1.02 \mathrm{~W} \cdot \mathrm{m}^{-2} \mathrm{~K}$. The obtained results for insulations of cooling tanks made of the polyurethane foam were similar to those of styrofoam insulations. According to the literature (Geryło, 2015), the heat transmission coefficient of the polyurethane foam may have a lower value. The studies concerning cooling tanks are preliminary studies performed with the use of prototype devices. Thus, firstly, one should focus on the improvement of the obtained coefficient. Natural materials may be also promising solutions of insulation of catering cooling furniture (Prazner et al., 2017; Góral et al., 2018), where the heat transmission coefficient $U$ is $0.75 \mathrm{~W} \cdot \mathrm{m}^{-2} \mathrm{~K}$ or mineral materials such as aerogels (Pietruszka, 2012; Adamczyk-Królak, 2015) for which the heat transmission coefficient $U$ is $0.35 \mathrm{~W} \cdot \mathrm{m}^{-2} \mathrm{~K}$. However, in order to make an insulation with the injection method into cooling furniture, one should firstly develop a suitable technology.

Referring the heat losses for the insulation made by injection of the foam into the space separating the tank from the casing to the insulation made of glued insulation material, it was clearly showed that the injection method was considerably more effective. The quantitative reduction of the heat stream through the innovative insulation was presented in fig. 10. On average, ca. $76 \%$ of the heat flowing through the wall with the glued insulation flew through 
the injected insulation. The average reduction of the heat feed is $24 \%$. It means that the average reduction of the heat stream to the value of ca. 0.76 in comparison to the glued insulation was obtained.

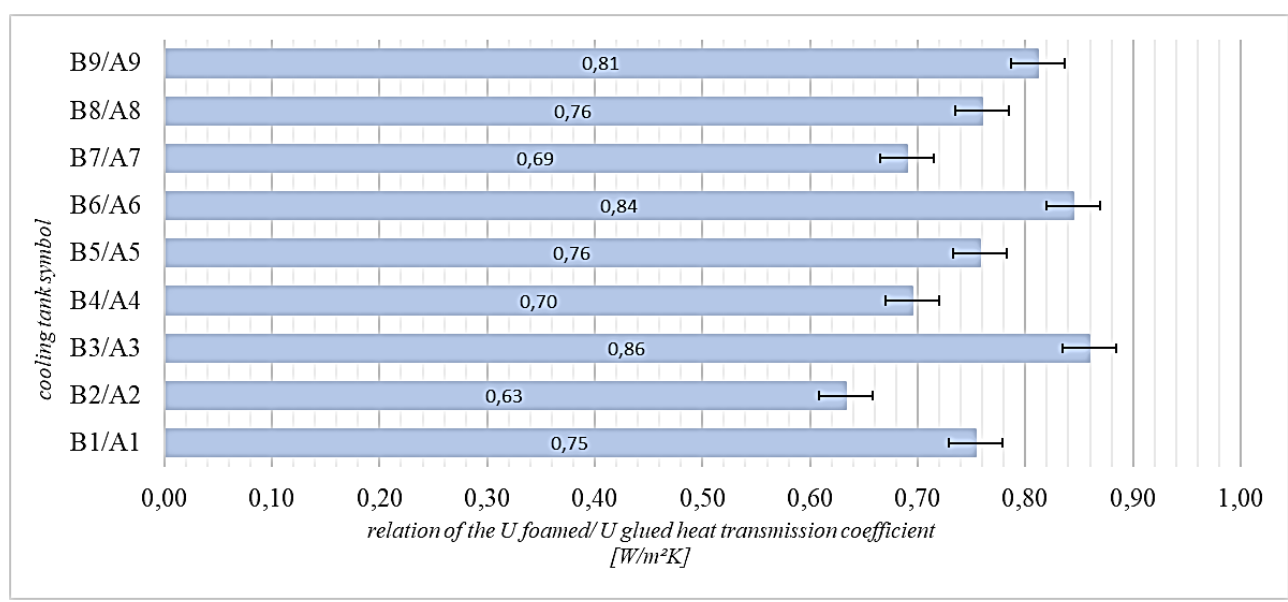

Figure 10. Assessment of heat losses reduction after the use of new technology of thermal insulation of the tank

\section{Assessment of occurrence of heat leakage bridges}

FLIR TG167 thermovision pyrometer was used for the analysis of occurrence and the impact of heat leakage bridges of the cooling tank. Tanks for which the heat transmission coefficient $U$ was obtained were investigated. Fig. 11-18 shows the exemplary results of thermovision measurements.

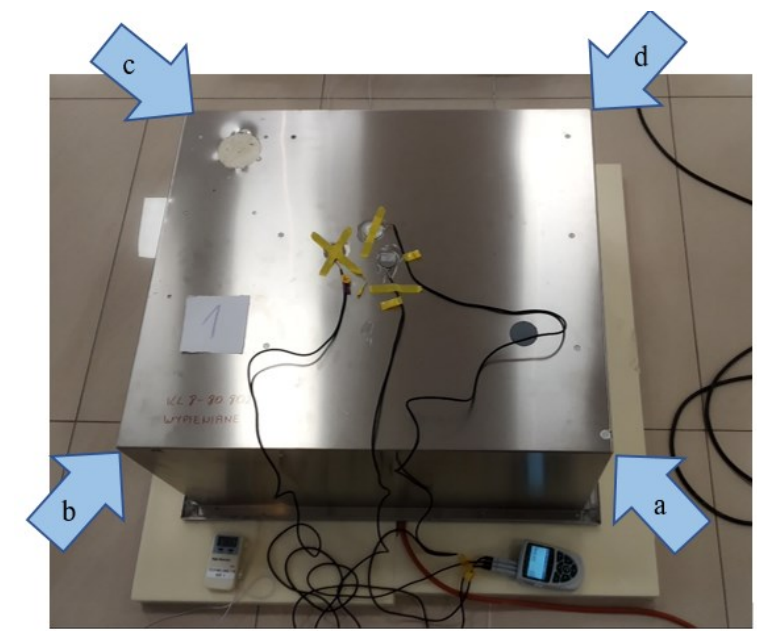

Figure 11. View of B1 tank (foaming insulation) 
Evaluation of thermal insulation...

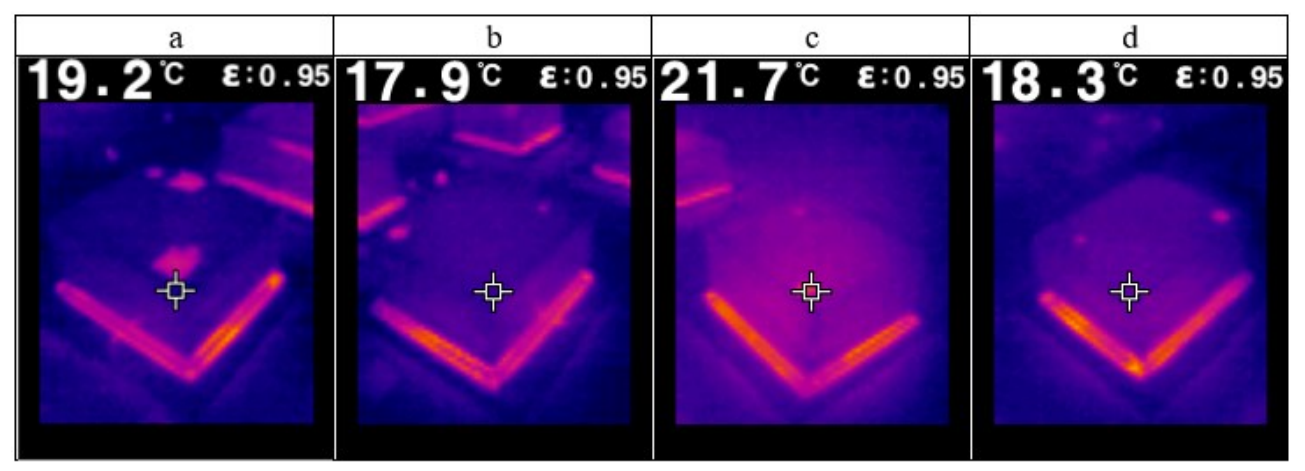

Figure 12. View of B1 tank (foaming insulation) in thermovision

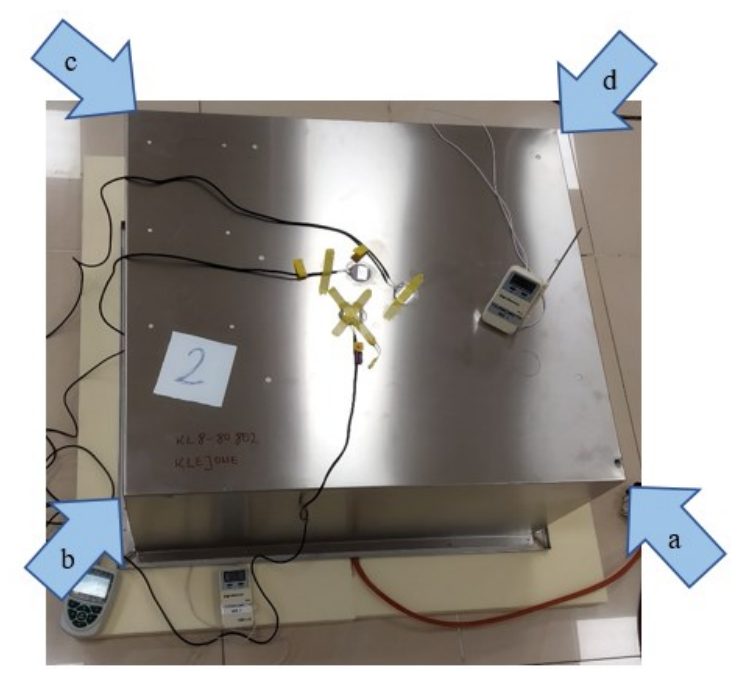

Figure 13. View of A1 tank (glued insulation)

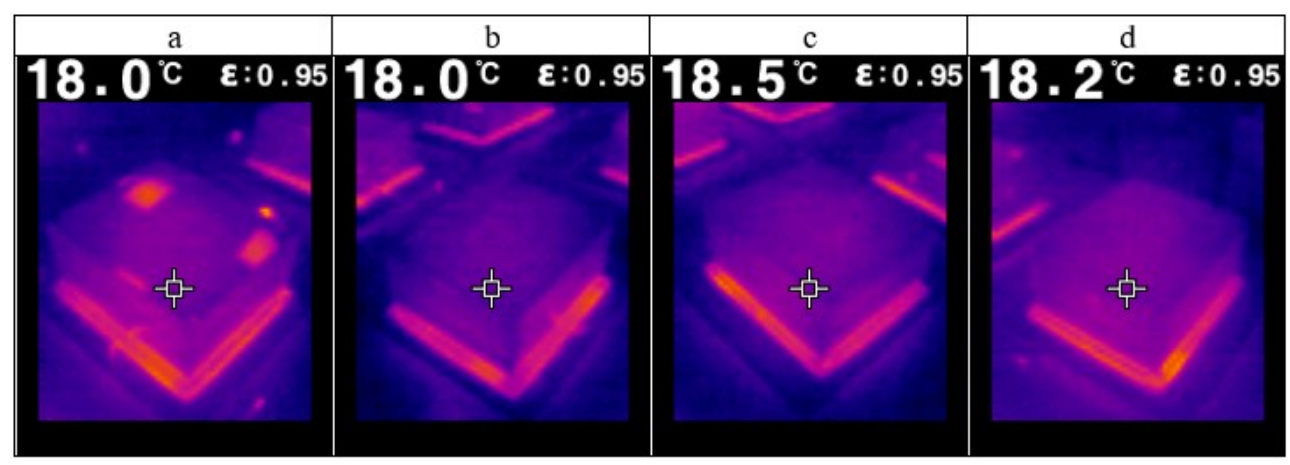

Figure 14. View of A1 tank (foaming insulation) in thermovision 


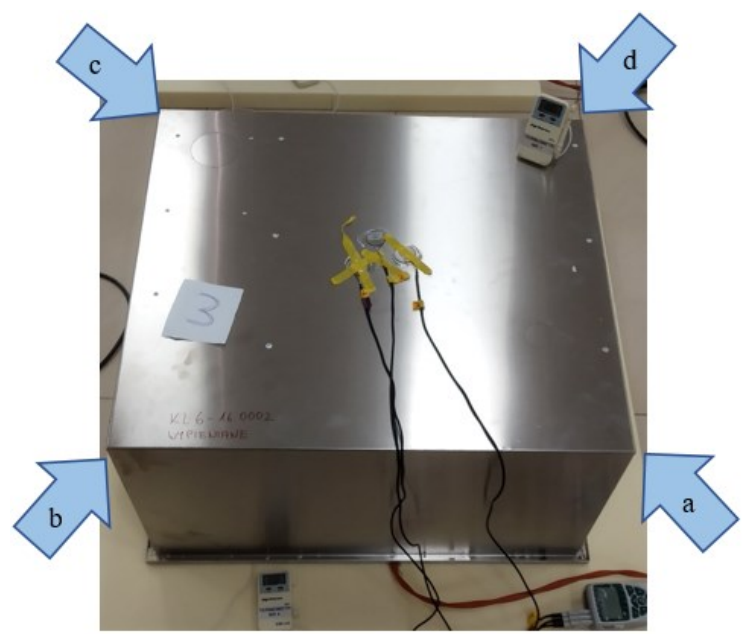

Figure 15. View of B2 tank (foaming insulation)

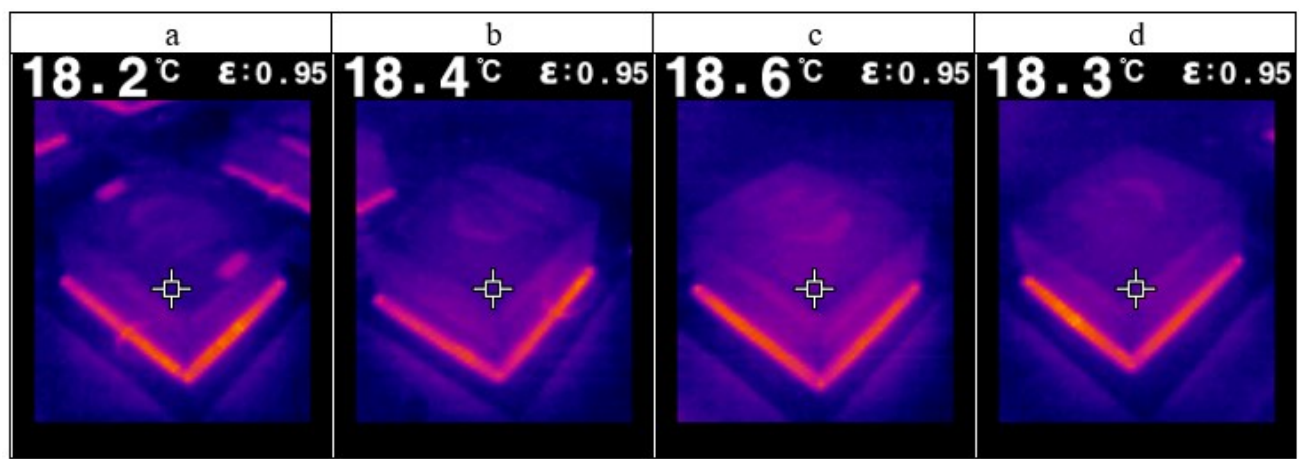

Figure 16. View of B2 tank (foaming insulation) in thermovision 


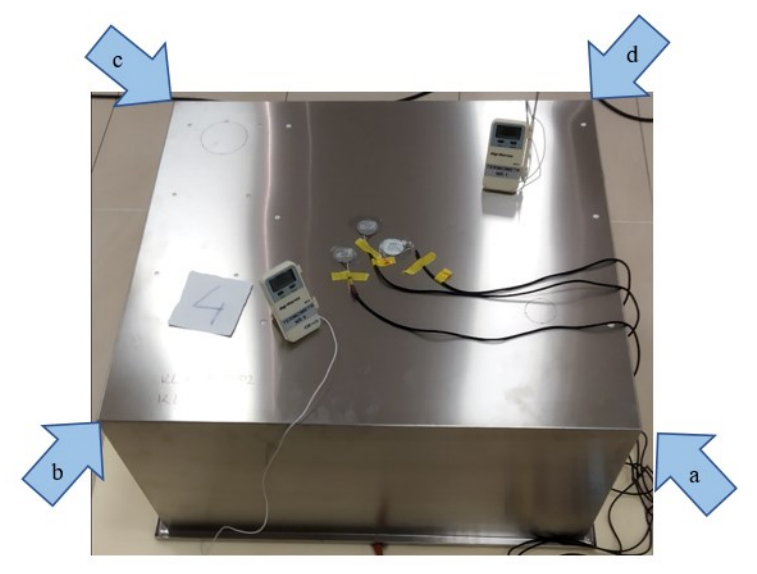

Figure 17. View of A2 tank (glued insulation)

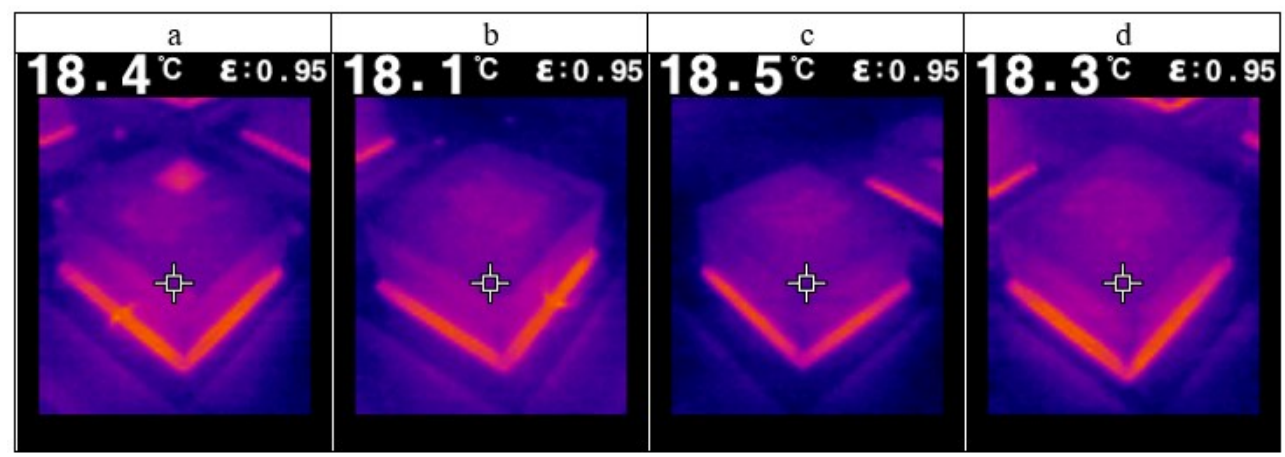

Figure 18. View of A2 tank (glued insulation) in thermovision

The obtained results of thermovision are compliant with the project assumptions and with the tests performed for the cooling bodies and food storage packaging (Góral et al., 2018; Rochatka, 2018; Rochatka, 2019). Both cooling tanks insulated with glued boards as well as cooling tanks, where the foam is injected did not show the existence of thermal bridges. Ensuring the continuity of insulation enables limitation of energy losses and ensures correct conditions for storing food. 


\section{Conclusions}

The tests that were performed confirmed that insulations made with the injection method have correct parameters. The heat permeability coefficient for the newly developed insulation method shows a lower value in comparison to the present method of glueing polyurethane boards. Comparison of the heat transmission coefficient of the innovative method and the method of gluing ready-made boards, proves that the new method enables to obtain improvement of insulation parameters by $24 \%$.

In the insulations made with the injection method, the thermovision tests proved that no heat leakage bridges occur. Taking into consideration the obtained results, one may state that the technological process is correct. The same situation takes place when the glued insulation of cooling tanks is analysed. Also in this case, there is a probability that tanks insulated in the previous years do not show energy losses by the occurrence of heat leakage bridges.

Introduction of more strict restrictions forces to create new insulation technologies in order to limit the negative impact on the environment. To conclude, the innovative insulation technology of cooling tank meets the expectations of both the manufacturing company and expectations towards the thermo-insulating materials.

\section{Funding}

The studies were performed as a part of the project Smart Growth Operational Programme 01.02.00-00-0098/17 "Development of the production technology of ergonomic furniture for serving lines that increase the comfort and safety of their use". The project was realized as a part of the sectoral programme "WoodINN", Operations 1.2 "Sector programmes R+D” the first priority axis „Support for R+D works carried out by the establishments of the Smart Growth Operational Programme 2014-2020. Beneficiary: Komat - Mieczysław Kozłowski

\section{References}

Adamczyk-Królak, I. (2015). Aerożele i pianki poliuretanowe - nowoczesne materiały termoizolacyjne w budownictwie. Budownictwo o Zoptymalizowanym Potencjale Energetycznym, 2, 9-14.

Bernat, T., Bieńczak, K. and Bogusławski, L. (2019). Description of energy balance for selected refrigeration furniture. Journal of Research and Applications in Agricultural Engineering, 2, 11-14.

Bieńczak, A., Ignasiak, Ł. and Woźniak, P. (2020). Building of calculation model and strength analysis by using finite element method on example of mold to foaming of cooling furniture. Journal of Research and Applications in Agricultural Engineering, 1, 4-8.

Bieńczak, K., Leszek, W., Nosal, S., Rochatka, T., Stachowiak, A., Tyczewski, P. and Zwierzycki, W. (2004). Fizyczne podstawy diagnostyki układów termoizolacyjnych do transportu żywności. Radom: ITE.

Brodt, K. (1995). Thermal insulations: CFC-alternatives and vacuum insulation. Leiden: Delft university of technology - Netherlands.

Geryło, R. (2015). Nowoczesny standard energetyczny budynków. Poradnik. Warszawa: POLCEN Sp. $\mathrm{z}$ o.o.

Góral, D., Kluza, F. i Kozłowicz, K. (2013). Bilans strat ciepła naczepy chłodniczej jako podstawa do prawidłowego doboru agregatu chłodniczego. Acta Scientiarum Polonorum. Technica Agraria, 12(11-22), 21-30. 
Evaluation of thermal insulation...

Góral, D., Kozłowicz, K., Kluza, F., Domin, M., Blicharz-Kania, A., Senetra, E., Dziki, D., Kocira, A. and Guz, T. (2018). Evaluation of thermophysical characteristics of freeze-dried protein foams as packaging material for frozen food. Przemyst Chemiczny, 5, 700-705.

Honeywell International Incorporation. (2021). Honeywell Refrigerants. Downloaded from location https:/www.honeywell-refrigerants.com/europe/wp-content/uploads/2018/11/Honeywell-SolsticeÂß-zd-Brohcure EN.pdf (Available: 10 May 2021)

Incropera, F.P. and DeWitt, D.P. (2002). Fundamentals of heat and mass transfer. Hoboken, USA: John Wiley \& Sons.

Jarfelt, U. i Ramnäs, O. (2006). Thermal conductivity of polyurethane foam - best performance. 10th International Symposium on District Heating and Cooling. Gotebörg. https://www.lsta.lt/files/events/28 jarfelt.pdf (Available: 10 may 2021)

Khalifa, A.J., Mustafa, A.T. and Khammas, F.A. (2011). Experimental Study of Temperature Stratification in a Thermal Storage Tank in the Static Mode for Different Aspect Ratios. ARPN Journal of Engineering and Applied Sciences, 6, 53-60.

Kozłowicz, K., Nazarewicz, S., Góral, D., Krawczuk, A. and Domin, M. (2019). Lyophilized Protein Structures as an Alternative Biodegradable Material for Food Packaging. Sustainability, 11(24), 7002.

Kuhn, J., Ebert, H.P., Arduini-Schuster, M. C., Buttner, D. and Fricke, J. (1992). Thermal transport in polystyrene and polyurethane foam insulations. International Journal Heat Mass Transfer, 35(7), 1795-1801.

Machado, C.M., Benelli, P. and Tessaro, I.C. (2017). Sesame cake incorporation on cassava starch foams for packaging use. Industrial Crops and Products, 102, 115-121.

Moreno, J.D. (1991). Radiative Transfer and Thermal Performance Levels in Foam Insulation Boardstocks. Massachussetts: B.S.C.E. Stanford University Massachussetts Institute of Technology.

Ostrorsky, A.G., Glicksman, L.R. and Reitz, D.W. (1986). Aging of polyurethane foams. International journal Heat Mass Transfer, 29(8), 1169-1176.

Page, M.C. (1991). Effects of alternating blowing agents on the aging of closed cell foam insulation. Massachussetts: B.S.C.E. Stanford University Massachussetts Institute of Technology.

Perz, K. (2005). Analiza przyczyn uszkodzeń płyt termoizolacyjnych w komorach chłodniczych. Problemy Eksploatacji, 1, 99-105.

Perz, K., Mamoński, Ł. and Rewolińska, A. (2018). Wpływ barwy nadwozia chłodniczego na jego parametry cieplne. Autobusy: technika, eksploatacja, systemy transportowe, 12, 589-592.

Pietruszka, B.L. (2012). Aerożele krzemionkowe jako komponent nowoczesnych izolacji cieplnych. Izolacje, 10, 20-23.

Prazner, Ł., Kozłowicz, K. and Podsiadło, H. (2017). Zmodyfikowane struktury żelatynowe - alternatywny materiał na opakowania żywności. Badanie właściwości termofizycznych i mechanicznych. Przemyst Spożywczy, 71(9), 58-62.

Rochatka, T. (2018). Analiza błędów konstrukcyjnych, technologicznych oraz eksploatacyjnych nadwozi izotermicznych i chłodniczych. Autobusy: technika, eksploatacja, systemy transportowe, 12, 615-619.

Rochatka, T. (2019). Measurements of heterogeneous heat streams permeating through damage to refrigerated bodies. Journal of Automation, Electronics and Electrical Engineering, 1, 23-27.

Sobolewski, M. and Błażejczyk, A. (2014). Thermal performance of high-pressure one-component foam in spray. Part 1. Properties and application of polyurethane foams. Izolacje, 11-12, 69-72.

United Nations Treaty Collection. Chapter XXVII 2.a Montreal Protocol on Substances that Deplete the Ozone Layer. (1987).

Vargas-Torres, A., Palma-Rodriguez, H.M., Berrios, J. D., Glenn, G., Salgado-Delgado, R., OlarteParedes, A. and Hernandez-Uribe, J.P. (2017). Biodegradable baked foam made with chayotextle starch mixed with plantain flour. Journal of Applied Polymer Science, 134, 455-465.

Wiśniewski, S. and Wiśniewski, T.S. (2000). Wymiana ciepła. Warszawa: Wydawnictwa Naukowo Techniczne. 


\title{
OCENA TERMOIZOLACJI PROTOTYPU GASRONOMICZNYCH MEBLI CHLODNICZYCH
}

\begin{abstract}
Streszczenie. Uwzględniając potrzeby zrównoważonego rozwoju podczas produkcji materiałów termoizolacyjnych, przebadana została innowacyjna metoda wtryskiwania materiału izolacyjnego do wnętrza wanny chłodniczej. Jako materiał izolacyjny wybrana została pianka poliuretanowa. Jako substancje odpowiedzialne za wypełnienie porów producent wybrał gazy z grupy fluoro-olefin (HFO), zatem produkt charakteryzujący się niewielkim wpływem na środowisko naturalne. Gazy z grupy fluoro-olefin (HFO) posiadają zerowy potencjał niszczenia warstwy ozonowej oraz bardzo niski potencjał globalnego ocieplenia. Wanny chłodnicze zaizolowane przy użyciu nowoczesnej technologii wtryskiwania piany poliuretanowej, przebadane zostały pod kątem współczynnika przenikania ciepła. Zostały także ocenione pod kątem występowania mostków cieplnych. Badaniom poddano także meble chłodnicze zaizolowane tradycyjna metoda wklejania gotowych płyt poliuretanowych. Przeprowadzone testy wykazały, że nowoczesna technologia izolowania wpływa na obniżenie współczynnika przenikania ciepła względem obecnie stosowanej technologii. Przebadana izolacja mebli chłodniczych nie wykazała występowania żadnych mostków cieplnych, zatem można wnioskować, że proces technologiczny jest prowadzony w prawidłowy sposób. Wanny chłodnicze wykonane w obecnej technologii izolowania także nie wykazały występowania mostków cieplnych.
\end{abstract}

Słowa kluczowe: meble chłodnicze, materiał termoizolacyjny, pianka poliuretanowa 